\title{
Effective Genre Classification - Understanding Url And Webpage Attributes For Classification
}

\author{
Aashlesha Bhingarde, Deepali Vora
}

\begin{abstract}
With the boom in the number of internet pages, it is very hard to discover desired records effortlessly and fast out of heaps of web pages retrieved with the aid of a search engine. there may be a increasing requirement for automatic type strategies with more class accuracy. There are a few conditions these days in which it's far vital to have an green and reliable classification of a web-web page from the information contained within the URL (Uniform aid Locator) handiest, with out the want to go to the web page itself. We want to understand if the URL can be used by us while not having to look and visit the page due to numerous motives. Getting the web page content material and sorting them to discover the genre of the net web page is very time ingesting and calls for the consumer to recognize the shape of the web page which needs to be categorised. To avoid this time-eating technique we proposed an exchange method so one can help us get the genre of the entered URL based of the entered URL and the metadata i.e., description, keywords used in the website along side the title of the web site. This approach does not most effective rely upon URL however also content from the internet application. The proposed gadget can be evaluated using numerous available datasets.
\end{abstract}

\section{key phrases-URL features, SVM, internet genre type.}

\section{INTRODUCTION}

To realize the genre of the webpage we want to recognize the structure of the internet web page. The hassle of web web page class is a complicated assignment, as a web web page carries now not only the textual data however also hyperlinks, images and multimedia. net web page content material extraction no longer simplest calls for the system to know the structure of the web page, but additionally require time for web crawling. This processing of extraction is each complicated and time-consuming as an internet web page is a complicated item that is composed of different sections belonging to distinctive genres. as an example, a convention net web page contains information at the conference, subjects covered, critical dates, contact statistics and a list of hypertext links to related facts.

the automated style category of internet pages is important for the personalization aspects of information retrieval, its accuracy in disambiguating content (word-sense disambiguation consistent with the style) and the development of language fashions. it could additionally be used for the predictive analysis of web browsing behavior. Genres are useful classes of records presentation. In other phrases, genres are the combination of favor, form, and content material. for example, books have many genres

\footnotetext{
Revised Manuscript Received on 16 September, 2019.

Aashlesha Bhingarde, Information Technology, Vidyalankar Institute of technology, Mumbai, Maharashtra, India

(email: aashubhingarde@gmail.com)

Prof. Deepali Vora, Information Technology, Vidyalankar Institute of technology, Mumbai, Maharashtra, India

(email: deepali.vora@vit.edu.in)
}

which includes poetry, play, novel, and biography and net pages have additionally advanced their very own genres inclusive of discussion boards, FAQs, blogs, and so on. essentially, the genre of a file is tied to its reason and shape.A Uniform Resource Locator (URL), colloquially termed a web address, is a reference to a web resource that specifies its location on a computer network and a mechanism for retrieving it. A URL is a specific type of Uniform Resource Identifier (URI), although many people use the two terms interchangeably. URLs occur most commonly to reference web pages (HTTP) but are also used for file transfer (FTP), email (mailto), database access (JDBC), and other applications.

Uniform resource locators (URLs), which mark the address of a resource on the World Wide Web, are often human-readable and can hint at the category of the resource. The blessings of URL type includes the subsequent: (i) capabilities are extracted from URLs alone thereby warding off the want for pointless downloads that waste bandwidth (ii) increases the rate of class (iii) beneficial for data filtering mission in blocking some websites earlier than accessing. but occasionally it isn't absolutely feasible to know the genre of the internet web page primarily based on just URL now and again additional records is required. We suggest a system that allows you to take metadata and title of the page into attention. The metadata will include description and keywords of the web page which we will get using web crawler. [4]

an internet crawler (also referred to as an internet spider or web robotic) is a program or automatic script which browses the sector extensive net in a methodical, automated manner. This process is known as net crawling or spidering Many legitimate sites, mainly, search engines like google, use spidering as a means of presenting up to date records. net crawlers are specifically used to create a duplicate of all the visited pages for later processing via a seek engine, with the intention to index the downloaded pages to provide fast searches. Crawlers also can be used for automating upkeep tasks on an internet website online, which includes checking links or validating HTML code.

With the use of net data and URL, endorse gadget so that you can classify the entered URL and will provide the genre of the entered input using the device mastering set of rules.

\section{II.EVALUATE OF LITERATURE}

\section{A. Table summary of literature evaluate}

web Url classification hassle has been studied by many 
researchers and different techniques, strategies were suggested inside the table of literature survey.[A]

\section{$B$. Inferences from the literature review}

From above desk of literature survey it's far seen that SVM has most accuracy also it has precision do not forget cost in better range so in our challenge we are the use of SVM set of rules for categorization of the URL and the extracted capabilities and the description, keywords and name. LSTM are not used in Neural network until now. And LSTM in gadget mastering have better accuracy than in Neural community. so as to discover which one is better for this discipline we are taken LSTM. As consistent with the literature survey Naive bias , N-gram, decision tree such algorithms are used for the classification of url. No work finished the use of LSTM in Neural Networks.so we are able to focus on this set of rules for categorization of url . and later we provide comparative take a look at of both the algorithms i.e SVM and LSTM to discover which set of rules will give better outcomes in phrases of accuracy.

\section{III.PROPOSED SYSTEM\& RESULTS}

here proposed system with a view to powerful in addition to much less time eating than the existing structures. This system will classify the web site primarily based on the URL, description, key phrases and name of the webpage. inside the gadget whilst the user enters the URL into the system internet crawling will be performed to get the info regarding title, description and keywords noted inside the metadata of the net web page. this is carried out as the primary idea concerning the genre may be taken from the description of the internet web page. those capabilities are extracted from the web site to be analyzed the use of the python library. those capabilities are then stored for further evaluation of the parameters.

the next part inside the manner is extracting n-gram features from the URL. but before doing that the URL is decrease-cased and we cut up the string at the punctuation marks(like /,-,.,\%). We also remove numbers and different non-letter characters so that the resulting output completely strings. as the string is cut up into numerous parts due to the removal of characters we get rid of strings of period less than 2 and HTTP for the consequent output. Later no stemming algorithm is used right here as we require the URL string to be in a proper form in order that we do now not lose any functions that can be applied when taking the capabilities from the string. [1] The approach this is used at the same time as taking the functions is n-grams. This technique splits the URL in the different tokens. Then letter n-grams, i.e., sequences of exactly $\mathrm{n}$ letters, are derived from them, and any token shorter than or identical to then the $n$ characters is kept unchanged. [10] as an instance, the token allwatchers offers upward push to the 5-grams "allwa", "llwat", "lwatc", "watch", "atche", "tcher" and "chers", but the token information can be saved intact. right here 4-gram functions approach is used to extract the capabilities .The n-gram characteristic and the function are expected in the machine which is trained using SVM and Deep gaining knowledge of set of rules to get an optimized result. This end result is then displayed at the output screen inside the internet utility. The data with a view to be utilized for processing is WebKB dataset for the category cause. Which encompass four folders of course, undertaking, school, pupil info. records may be collected from these folders and preprocess it.

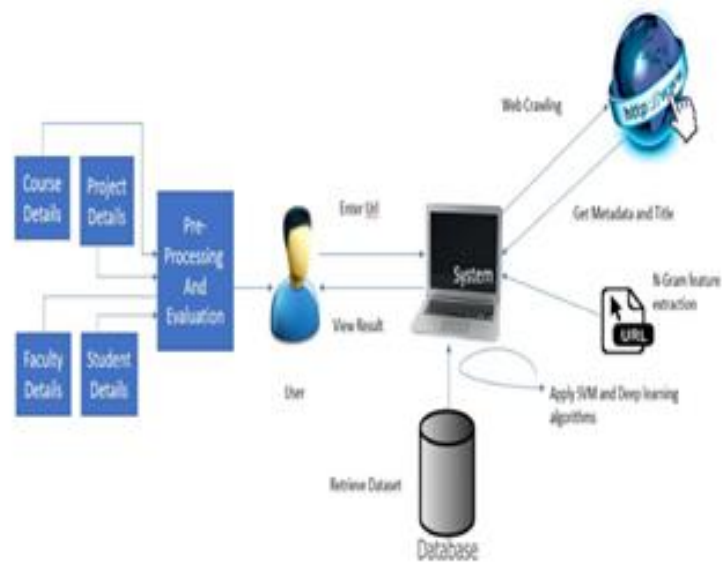

Blocks of system design :.

[1] course info :It contains the route urls containing statistics. route subtleties comprise variety of organizers in which rundown obviously related website names are located away.

[2] venture information : It includes the undertaking urls containing information. The subtleties encompass variety of envelopes in which rundown of mission related internet site names are put away.

[3] personnel details : It includes the faculty urls containing data. The subtleties incorporate type of organizers in which rundown of personnel associated internet web page names are positioned away.

[4] Understudy details : It carries the pupil urls containing records. The subtleties include amount of organizers in which rundown of understudy associated web page names are positioned away.

[5] Pre-getting prepared : wherein we can smooth the statistics and keep it for further dealing with.

[6] assessment : statistics is then element into check and train dataset.

[7] customer : The patron will enter the URL as contribution to the application.

[8] internet crawler : it's far carried out to get the portrayal, perceive and catchphrases from the internet site net web page to realize all the extra with admire to the entered URL.

[9] N-Gram highlight extraction : The highlights of URL will be eliminated, as an example, length, kind, characters with the usage of n-gram consist of extraction calculation. [1]

[10] SVM set of rules and Deep analyzing Algorithms : The association of the URL is finished using SVM set of rules and using Deep studying calculations the eliminated highlights and the portrayal, watchwords and name. 
[11] course information :It consists of the path urls containing information. route subtleties incorporate quantity of organizers

[12] method

[13] - The customer will input the URL as contribution to the software.

[14] - we will utilize net crawler to get the portrayal, comprehend all the greater with respect to the entered URL.

[15] - The highlights of URL can be removed, for example, duration, type, characters with the usage of ngram consist of extraction calculation.

[16] - The class of the URL is completed making use of SVM set of rules and Deep mastering the separated highlights and the depiction, watchwords and name.

[17] - The outcome showed will encompass of removed highlights and the class of the URL.

\section{CONCLUSION}

Characterization of website pages depending on the URL and web page trends, as an instance, metadata and URL, is useful as it abstains from bringing the website online pages superfluously for viable type order. website online web page association depending on URLs by myself assumes a widespread activity for the cause that substance of net site pages want now not be gotten for grouping. Be that as it may, the URL is extraordinarily succinct and might be made from related phrases so arrangement with without a doubt this facts is a difficult errand. To hold a strategic distance from this tedious technique we proposed an different method if you want to enable us to get the class of the entered URL primarily based totally of the entered URL and the metadata, i.E., depiction, catchphrases applied inside the net website web page along the identify of the page. This technique might be depend upon URLs really as substance from the net software.

The proposed framework could have the choice to offer us the magnificence of the entered net URL utilizing the URL and the metadata and identify of the site web page which we get making use of the net crawler. The metadata encompass catchphrases and depiction. The highlights of URL may be separated, for instance, period, kind, characters with the usage of $n$-gram encompass extraction calculation. The statistics on the way to be used for preparing is WebKB dataset for the order cause. The order of the URL is finished making use of SVM set of rules and utilizing Deep getting to know calculations the separated highlights and the depiction, watchwords and call of the page to make the framework regularly precise. The system might be tested technique's viability the usage of diverse parameters like exactness, accuracy and large scale determined the middle charge of F-degree

\section{REFERENCES}

1. R. Rajalakshmi, Sanju Xaviar, "check have a look at Of function Weighting strategies For URL primarily based web site category", seventh global conference on Advances in Computing and Communications, ICACC2017

2. Min-Yen Kan, "website internet page arrangement without the web website online internet web page", call and catchphrases from the web web page web page to

proceedings of the thirteenth international international huge web assembly on alternate track papers and notices, 2004

3. Jin-Cheon Na, Tun Thura Thet "Viability of internet seek outcomes for genre and Sentiment class", journal of data technological know-how, 2009

4. Neetu Singh, Narendra S. Chaudhari, "N-gram approach for a URL Similarity degree", first India worldwide conference on data Processing (IICIP),2016

5. Eda Baykan, Monika Henzinger, Ludmila Marian, Ingmar Weber, "simply URL-based totally absolutely topic classification", proceedings of the eighteenth international convention on global extensive, 2009

6. R. Rajalakshmi, "recognizing health area URLs utilizing SVM", court cases of the 1/3 international Symposium on ladies in Computing and Informatics, 2015

7. R. Rajalakshmi and Chandrabose Aravindan, "website online web page class utilising n-gram based totally URL features", fifth global convention on superior Computing, 2013

8. Min-Yen Kan, Hoang Oanh Nguyen Thi, "short website on-line web page characterization using URL highlights", complaints of the fourteenth ACM international assembly on records and studying the executives, 2005

9. Myriam Abramson, David W. Aha, "what's in a URL? kind classification from URLs", intelligent strategies for internet Personalization and Recommender structures, 2012

10. Tarek Amr Abdallah and Beatriz de la Iglesia, "URLbased totally internet web page classification: With nGram Language fashions", court cases of the international Joint conference on knowledge Discovery, know-how Engineering and information control, 2014

11. Chaker Jebari, M. Arif Wani, "A Multi-mark and Adaptive genre classification of net Pages", 11th global conference on machine gaining knowledge of and packages, 2012

12. R. Rajalakshmi, C. Aravindan, "Credulous Bayes technique for website type", records technology and cellular communication: worldwide conference,2011

13. Jebari Chaker, Ounelli Habib, "kind class of website online pages", seventh IEEE global conference on information Mining, 2008

14. Chaker Jebari "A natural URL-based totally totally style type of internet Pages", twenty fifth international Workshop on Database and professional structures packages, 2014

15. R. Rajalakshmi "Regulated term WEIGHTING methods FOR URL category", journal of pc technology,2014

16. Sanjay okay. Dwivedi, Chandrakala Arya, "news net page classification the usage of Url content and shape Attributes", second global convention on subsequent generation Computing technologies, 2016

17. EDA BAYKAN, MONIKA HENZINGER, LUDMILA MARIAN, INGMAR WEBER, "A complete have a look at of capabilities and Algorithms for URL-primarily based subject matter type", ACM Transactions at the net, 2011

18. Sini Shibu, Aishwarya Vishwakarma and Niket Bhargava, "a blend approach for internet page category using page Rank and feature selection approach"

19. Di Pan, Ke Yu, Xiaofei Wu, Binbin Wang, Yaowen Tan "web primarily based company user behavior classification primarily based on URL facts From Telecom DPI information", IEEE/CIC worldwide conference on Communications in China (ICCC), 2017. 
Effective Genre Classification - Understanding Url And Webpage Attributes For Classification

[A] TABLE SUMMARY OF LITERATURE REVIEW

\begin{tabular}{|c|c|c|c|c|c|c|}
\hline $\begin{array}{l}\mathbf{N} \\
\mathbf{0}\end{array}$ & $\begin{array}{l}\text { Autho } \\
\text { rs }\end{array}$ & $\begin{array}{l}\text { Publi } \\
\text { catio } \\
\text { n } \\
\text { Year }\end{array}$ & $\begin{array}{l}\text { Key } \\
\text { Findings }\end{array}$ & $\begin{array}{l}\text { Drawb } \\
\text { acks }\end{array}$ & $\begin{array}{l}\text { Appr } \\
\text { oache } \\
\text { s }\end{array}$ & $\begin{array}{l}\text { Evaluation } \\
\text { Measures } \\
\text { and value }\end{array}$ \\
\hline $\begin{array}{l}{[1} \\
]\end{array}$ & $\begin{array}{l}\text { R. } \\
\text { Rajala } \\
\text { kshmi, } \\
\text { Sanju } \\
\text { Xaviar }\end{array}$ & 2017 & $\begin{array}{l}\text { Macro } \\
\text { average F1 } \\
\text { score is } \\
\text { better than } \\
\text { SVM. }\end{array}$ & $\begin{array}{l}\text { Only } \\
\text { web } \\
\text { URL is } \\
\text { used } \\
\text { for } \\
\text { classifi } \\
\text { cation } \\
\text { other } \\
\text { factors } \\
\text { are not } \\
\text { consid } \\
\text { ered } \\
\text { during } \\
\text { the } \\
\text { classifi } \\
\text { cation. }\end{array}$ & $\begin{array}{l}\text { featur } \\
\text { e } \\
\text { weigh } \\
\text { ting } \\
\text { metho } \\
\text { d }\end{array}$ & $\begin{array}{l}\text { macro } \\
\text { average F1 } \\
(79 \%)\end{array}$ \\
\hline $\begin{array}{l}{[2} \\
]\end{array}$ & $\begin{array}{l}\text { Min- } \\
\text { Yen } \\
\text { Kan }\end{array}$ & 2004 & $\begin{array}{l}\text { Appropriat } \\
\text { e use of } \\
\text { URL alone } \\
\text { proves } \\
\text { about } \\
\text { three- } \\
\text { fourths as } \\
\text { effective } \\
\text { using the } \\
\text { page text } \\
\text { itself and } \\
\text { exceeds } \\
\text { the } \\
\text { performan } \\
\text { ce of } \\
\text { systems } \\
\text { using the } \\
\text { page title } \\
\text { or its } \\
\text { anchors } \\
\text { words. }\end{array}$ & $\begin{array}{l}\text { The } \\
\text { URL } \\
\text { only } \\
\text { feature } \\
\text { s } \\
\text { classifi } \\
\text { cation } \\
\text { fails to } \\
\text { improv } \\
\text { e the } \\
\text { perfor } \\
\text { mance } \\
\text { of } \\
\text { knowle } \\
\text { dge- } \\
\text { rich } \\
\text { classifi } \\
\text { ers that } \\
\text { have } \\
\text { access } \\
\text { to all } \\
\text { availab } \\
\text { le } \\
\text { feature } \\
\text { s }\end{array}$ & $\begin{array}{l}\text { SVM } \\
\text { machi } \\
\text { ne } \\
\text { learne } \\
\mathrm{r}\end{array}$ & $\begin{array}{l}\text { Macro } \\
\text { average (43.2) }\end{array}$ \\
\hline $\begin{array}{l}{[3} \\
]\end{array}$ & $\begin{array}{l}\text { Jin- } \\
\text { Cheon } \\
\text { Na, } \\
\text { Tun } \\
\text { Thura } \\
\text { Thet }\end{array}$ & 2009 & $\begin{array}{l}\text { SVM } \\
\text { performs } \\
\text { the best } \\
\text { with the } \\
\text { title, } \\
\text { summary } \\
\text { text, and } \\
\text { URL of the } \\
\text { snippets } \\
\text { from } \\
\text { various } \\
\text { review } \\
\text { sites as } \\
\text { phrase } \\
\text { terms (n- } \\
\text { grams) }\end{array}$ & $\begin{array}{l}\text { Result } \\
\text { is } \\
\text { given } \\
\text { to only } \\
\text { electro } \\
\text { nic } \\
\text { produc } \\
\mathrm{t} \\
\text { review } \\
\text { but for } \\
\text { other } \\
\text { domai } \\
\text { ns the } \\
\text { the } \\
\text { classifi } \\
\text { cation } \\
\text { is not } \\
\text { accurat }\end{array}$ & SVM & $\begin{array}{l}\text { Accuracy } \\
(84.08)\end{array}$ \\
\hline
\end{tabular}

\begin{tabular}{|c|c|c|c|c|c|c|}
\hline & & & & e. & & \\
\hline $\begin{array}{l}{[4} \\
]\end{array}$ & $\begin{array}{l}\text { Neetu } \\
\text { Singh, } \\
\text { Narend } \\
\text { ra S. } \\
\text { Chaud } \\
\text { hari }\end{array}$ & 2016 & $\begin{array}{l}\mathrm{N} \text {-gram } \\
\text { approach } \\
\text { outperform } \\
\text { s the } \\
\text { Jaccard, } \\
\text { Cosine and } \\
\text { Dice } \\
\text { distance } \\
\text { measures }\end{array}$ & $\begin{array}{l}\text { Experi } \\
\text { mentin } \\
g \text { with } \\
\text { 5-gram } \\
\text { or } \\
\text { more is } \\
\text { not } \\
\text { feasibl } \\
\text { e we } \\
\text { keep } \\
\text { on } \\
\text { increas } \\
\text { ing the } \\
\text { value } \\
\text { of 'n' } \\
\text { then } \\
\text { the } \\
\text { numbe } \\
\text { r of } \\
\text { test } \\
\text { URLs } \\
\text { that the } \\
\text { classifi } \\
\text { er is } \\
\text { able to } \\
\text { classif } \\
\text { y } \\
\text { keeps } \\
\text { on } \\
\text { decrea } \\
\text { sing. }\end{array}$ & $\begin{array}{l}\text { Cosin } \\
\text { e } \\
\text { simila } \\
\text { rity } \\
\text { and } \\
\text { Jaccar } \\
\text { d } \\
\text { distan } \\
\text { ce }\end{array}$ & $\begin{array}{l}\text { Miscalculatio } \\
\text { n Rate } \\
(33.51),(30.13 \\
),(34.06)\end{array}$ \\
\hline $\begin{array}{l}{[5} \\
]\end{array}$ & $\begin{array}{l}\text { Eda } \\
\text { Bayka } \\
\mathrm{n}, \\
\text { Monik } \\
\text { a } \\
\text { Henzin } \\
\text { ger, } \\
\text { Ludmil } \\
\text { a } \\
\text { Marian } \\
\text {, }\end{array}$ & 2009 & $\begin{array}{l}\text { Macro- } \\
\text { averaged } \\
\text { F-measure } \\
\text { was } 75.6, \\
81.8 \text { and } \\
82.4 \text { for } \\
\text { tokens, 4- } \\
\text { grams and } \\
\text { all-grams } \\
\text { respectivel } \\
\text { y with } \\
\text { SVM } \\
\text { classifier }\end{array}$ & - & SVM & $\begin{array}{l}\text { Precision }(82.4 \\
), \\
\text { Recall(80.10), } \\
\text { F1(85.4) }\end{array}$ \\
\hline $\begin{array}{l}{[6} \\
]\end{array}$ & $\begin{array}{l}\text { R. } \\
\text { Rajala } \\
\text { kshmi }\end{array}$ & 2015 & $\begin{array}{l}\text { SVM gives } \\
\text { a better } \\
\text { precision } \\
\text { than the } \\
\text { SVM, Stat. } \\
\text { Dict, } \\
\text { Navie } \\
\text { Bays }\end{array}$ & $\begin{array}{l}\text { uses } \\
\text { only } \\
\text { the 4- } \\
\text { grams } \\
\text { feature } \\
\text { s }\end{array}$ & $\begin{array}{l}\text { SVM } \\
\text { with } \\
\text { linear } \\
\text { kernel }\end{array}$ & $\begin{array}{l}\text { Precision }(81 \\
\%)\end{array}$ \\
\hline $\begin{array}{l}\mathbf{N} \\
\mathbf{0}\end{array}$ & $\begin{array}{l}\text { Autho } \\
\text { rs }\end{array}$ & $\begin{array}{l}\text { Publi } \\
\text { catio } \\
\text { n } \\
\text { Year }\end{array}$ & $\begin{array}{l}\text { Key } \\
\text { Findings }\end{array}$ & $\begin{array}{l}\text { Drawb } \\
\text { acks }\end{array}$ & $\begin{array}{l}\text { Appr } \\
\text { oache } \\
\text { s }\end{array}$ & $\begin{array}{l}\text { Evaluation } \\
\text { Measures } \\
\text { and value }\end{array}$ \\
\hline $\begin{array}{l}{[7} \\
]\end{array}$ & $\begin{array}{l}\text { R. } \\
\text { Rajala } \\
\text { kshmi } \\
\text { and } \\
\text { Chandr } \\
\text { abose }\end{array}$ & 2013 & $\begin{array}{l}\text { SVM and } \\
\text { ME } \\
\text { performed } \\
\text { equally } \\
\text { Does not }\end{array}$ & - & $\begin{array}{l}\text { SVM } \\
\text { and } \\
\text { Maxi } \\
\text { and Eng } \\
\text { mum } \\
\text { entrop } \\
\text { y }\end{array}$ & $\begin{array}{l}\text { Precision(78.1 } \\
7 \%), \\
\text { Recall( }(78.44 \\
\% \%, f 1(78.23 \% \\
0\end{array}$ \\
\hline
\end{tabular}




\begin{tabular}{|c|c|c|c|c|c|c|c|c|c|c|c|c|c|}
\hline & $\begin{array}{l}\text { Aravin } \\
\text { dan }\end{array}$ & & $\begin{array}{l}\text { take into } \\
\text { considerati } \\
\text { on tokens } \\
\text { and other } \\
\text { n-gram } \\
\text { features }\end{array}$ & & $\begin{array}{l}\text { classif } \\
\text { ier }\end{array}$ & & & dan & & & $\begin{array}{l}\text { websit } \\
\text { es } \\
\text { purely } \\
\text { based } \\
\text { on the } \\
\text { URLs }\end{array}$ & & \\
\hline \multirow[t]{2}{*}{ [8 } & \multirow[t]{2}{*}{$\begin{array}{l}\text { Min- } \\
\text { Yen } \\
\text { Kan, } \\
\text { Hoang } \\
\text { Oanh } \\
\text { Nguye } \\
\text { n Thi }\end{array}$} & \multirow[t]{2}{*}{2005} & \multirow{2}{*}{$\begin{array}{l}\text { URL } \\
\text { features } \\
\text { also } \\
\text { correlate } \\
\text { with } \\
\text { Pagerank } \\
\text { in our } \\
\text { topical } \\
\text { collection, } \\
\text { allowing } \\
\text { prediction } \\
\text { of } \\
\text { Pagerank } \\
\text { within 1 } \\
\text { point on } \\
\text { average on } \\
\text { Google's } \\
\text { 10-point } \\
\text { scale }\end{array}$} & \multirow[t]{2}{*}{-} & \multirow[t]{2}{*}{$\begin{array}{l}\text { maxi } \\
\text { mum } \\
\text { entrop } \\
y\end{array}$} & \multirow[t]{2}{*}{$\begin{array}{l}\text { Accuracy(50. } \\
\%), F 1(15.10 \\
\%)\end{array}$} & $\begin{array}{l}{[1} \\
3]\end{array}$ & $\begin{array}{l}\text { Jebari } \\
\text { Chaker } \\
\text { Ounelli } \\
\text { Habib }\end{array}$ & 2008 & $\begin{array}{l}\text { It was } \\
\text { concluded } \\
\text { that } \\
\text { TFIDF/Ro } \\
\text { cchio is the } \\
\text { best } \\
\text { classifier } \\
\text { for all } \\
\text { combinatio } \\
\text { ns of } \\
\text { features }\end{array}$ & - & $\begin{array}{l}\text { KNN } \\
\text { and } \\
\text { SVM }\end{array}$ & $\begin{array}{l}\text { Micro- } \\
\text { averaged } \\
\operatorname{BEP}(79.75 \%) \\
\text { and }(74.12 \%)\end{array}$ \\
\hline & & & & & & & \multirow[t]{2}{*}{$\begin{array}{l}1 \\
4]\end{array}$} & \multirow[t]{2}{*}{$\begin{array}{l}\text { Chaker } \\
\text { Jebari }\end{array}$} & \multirow[t]{2}{*}{2014} & \multirow{2}{*}{$\begin{array}{l}\text { MLKNN } \\
\text { achieves } \\
\text { the best } \\
\text { results } \\
\text { with } \\
\text { respect to } \\
\text { all } \\
\text { experiment } \\
\text { ation } \\
\text { metrics, } \\
\text { followed } \\
\text { by BR- } \\
\text { SVM, } \\
\text { Rakel and } \\
\text { BPMLL }\end{array}$} & \multirow[t]{2}{*}{-} & \multirow[t]{2}{*}{$\begin{array}{l}\text { MLK } \\
\text { NN }\end{array}$} & \multirow{2}{*}{$\begin{array}{l}\text { HamLoss(8\%) } \\
\text { OneError(9\%) } \\
\text { RankLoss(3\% } \\
\text { ), } \\
\text { Coverage(7.6 } \\
8 \%), \text { Micro- } \\
\text { Precision(7.70 } \\
\%)\end{array}$} \\
\hline \multirow[t]{2}{*}{$\begin{array}{l}{[9} \\
]\end{array}$} & \multirow[t]{2}{*}{$\begin{array}{l}\text { Myria } \\
\text { m } \\
\text { Abram } \\
\text { son, } \\
\text { David } \\
\text { W. } \\
\text { Aha }\end{array}$} & \multirow[t]{2}{*}{2012} & \multirow[t]{2}{*}{$\begin{array}{l}\text { NB } \\
\text { classifier } \\
\text { works } \\
\text { better than } \\
\text { SVM }\end{array}$} & $\begin{array}{l}\text { There } \\
\text { are a } \\
\text { numbe } \\
r \text { of } \\
\text { unclass } \\
\text { ified } \\
\text { web } \\
\text { pages }\end{array}$ & \multirow[t]{2}{*}{$\begin{array}{l}\text { n- } \\
\text { gram } \\
\text { featur } \\
\text { e }\end{array}$} & \multirow[t]{2}{*}{$\begin{array}{l}\text { Precision(57 } \\
\%), \\
\text { Recall(47\%) }\end{array}$} & & & & & & & \\
\hline & & & & $\begin{array}{l}\text { in the } \\
\text { dataset }\end{array}$ & & & \multirow[t]{3}{*}{$\begin{array}{l}1 \\
5]\end{array}$} & \multirow[t]{3}{*}{$\begin{array}{l}\text { R. } \\
\text { Rajala } \\
\text { kshmi }\end{array}$} & \multirow[t]{3}{*}{2014} & \multirow{3}{*}{$\begin{array}{l}\text { They } \\
\text { compared } \\
\text { the } \\
\text { precision } \\
\text { of } \\
\text { individual } \\
\text { classifiers } \\
\text { of Naïve } \\
\text { Bayes } \\
\text { multiclass } \\
\text { classifier } \\
\text { with four- } \\
\text { term } \\
\text { weighting } \\
\text { schemes }\end{array}$} & \multirow{3}{*}{$\begin{array}{l}\text { This } \\
\text { approa } \\
\text { ch is } \\
\text { purely } \\
\text { based } \\
\text { on } \\
\text { URL } \\
\text { and its } \\
\text { feature } \\
\text { s }\end{array}$} & \multirow[t]{3}{*}{$\begin{array}{l}\text { Naive } \\
\text { Bayes }\end{array}$} & \multirow[t]{3}{*}{$\begin{array}{l}\text { Precision(22 } \\
\%), F 1(11 \%)\end{array}$} \\
\hline $\begin{array}{l}{[1} \\
0]\end{array}$ & $\begin{array}{l}\text { Tarek } \\
\text { Amr } \\
\text { Abdall } \\
\text { ah and } \\
\text { Beatriz } \\
\text { de La } \\
\text { Iglesia }\end{array}$ & 2014 & $\begin{array}{l}\text { Best } \\
\text { results for } \\
\text { the n-gram } \\
\text { LM were } \\
\text { achieved } \\
\text { using 7- } \\
\text { grams and } \\
\gamma=0.004 \text {. }\end{array}$ & $\begin{array}{l}\text { Interpo } \\
\text { lation } \\
\text { of } \\
\text { multipl } \\
\text { e n- } \\
\text { gram } \\
\text { models } \\
\text { is not } \\
\text { present }\end{array}$ & $\begin{array}{l}\mathrm{n}- \\
\text { gram }\end{array}$ & $\begin{array}{l}\text { Average } \\
\text { f1 }(66.50 \%)\end{array}$ & & & & & & & \\
\hline \multirow[t]{3}{*}{$\begin{array}{l}1 \\
1]\end{array}$} & \multirow{3}{*}{$\begin{array}{l}\text { Chaker } \\
\text { Jebari, } \\
\text { M. } \\
\text { Arif } \\
\text { Wani }\end{array}$} & \multirow[t]{3}{*}{2012} & \multirow{3}{*}{$\begin{array}{l}\text { Proposed } \\
\text { approach } \\
\text { is better } \\
\text { than Rakel, } \\
\text { BR-SVM, } \\
\text { MLKNN } \\
\text { and } \\
\text { BPMLL. }\end{array}$} & \multirow{3}{*}{$\begin{array}{l}\text { It just } \\
\text { uses } \\
\text { NLP to } \\
\text { classif } \\
\text { y the } \\
\text { URL } \\
\text { withou } \\
\text { t any } \\
\text { machin } \\
\text { e } \\
\text { learnin } \\
\text { g } \\
\text { algorit } \\
\text { hm }\end{array}$} & \multirow[t]{3}{*}{$\begin{array}{l}\mathrm{n}- \\
\text { gram }\end{array}$} & \multirow{3}{*}{$\begin{array}{l}\text { Precision(94 } \\
\%), \\
\text { rankLoss }(81 \% \\
), \text { One } \\
\text { Error(5\%), } \\
\text { HamLoss }(6 \%)\end{array}$} & & & & & & & \\
\hline & & & & & & & $\begin{array}{l}\mathbf{N} \\
\mathbf{o}\end{array}$ & $\begin{array}{l}\text { Autho } \\
\text { rs }\end{array}$ & $\begin{array}{l}\text { Publi } \\
\text { catio } \\
\text { n } \\
\text { Year }\end{array}$ & $\begin{array}{l}\text { Key } \\
\text { Findings }\end{array}$ & $\begin{array}{l}\text { Drawb } \\
\text { acks }\end{array}$ & $\begin{array}{l}\text { Appr } \\
\text { oache } \\
\text { s }\end{array}$ & $\begin{array}{l}\text { Evaluation } \\
\text { Measures } \\
\text { and value }\end{array}$ \\
\hline & & & & & & & $\begin{array}{l}{[1} \\
6]\end{array}$ & $\begin{array}{l}\text { Sanjay } \\
\text { K. } \\
\text { Dwive } \\
\text { di, } \\
\text { Chandr } \\
\text { akala }\end{array}$ & 2016 & $\begin{array}{l}\text { Naïve } \\
\text { Bayes } \\
\text { perform } \\
\text { better than } \\
\text { other } \\
\text { algorithms }\end{array}$ & $\begin{array}{l}\text { System } \\
\text { is } \\
\text { purely } \\
\text { based } \\
\text { on } \\
\text { news }\end{array}$ & $\begin{array}{l}\text { Naïve } \\
\text { Bayes } \\
\text { classif } \\
\text { ier }\end{array}$ & $\begin{array}{l}\text { Precision }(96.5 \\
\%)\end{array}$ \\
\hline $\begin{array}{l}1 \\
2]\end{array}$ & $\begin{array}{l}\text { R. } \\
\text { Rajala } \\
\text { kshmi, } \\
\text { C. } \\
\text { Aravin }\end{array}$ & 2011 & $\begin{array}{l}\text { Performan } \\
\text { ce of the } \\
\text { system } \\
\text { was } \\
\text { evaluated }\end{array}$ & $\begin{array}{l}\text { The } \\
\text { propos } \\
\text { ed } \\
\text { system } \\
\text { classifi } \\
\text { es }\end{array}$ & $\begin{array}{l}\text { Naive } \\
\text { Bayes } \\
\text { algorit } \\
\mathrm{hm}\end{array}$ & $\begin{array}{l}\text { Precision(70 } \\
\%), \\
\text { Recall }(88 \%) \\
\text { and F- } \\
\text { measure }(76 \%)\end{array}$ & & Arya & & $\begin{array}{l}\text { which } \\
\text { provides } \\
\text { adequate } \\
\text { classificati } \\
\text { on } \\
\text { accuratene }\end{array}$ & $\begin{array}{l}\text { web } \\
\text { pages. } \\
\text { It } \\
\text { cannotoo } \\
\text { be so s. } \\
\text { usêّ in }\end{array}$ & & \\
\hline $\begin{array}{l}\text { Ret } \\
\text { DO }\end{array}$ & ieval Num & irte.B & $\begin{array}{l}0982 S 1119 / 2 \\
1.0982 S 111\end{array}$ & $9 \odot B E$ & & & & $\begin{array}{l}\text { Publish } \\
\text { Blue E. } \\
\text { \& Scier }\end{array}$ & es $P u$ & $\begin{array}{l}\text { nce Engine } \\
\text { ation }\end{array}$ & & & \\
\hline
\end{tabular}




\begin{tabular}{|l|l|l|l|l|l|l|}
\hline |l & & $\begin{array}{l}\text { ss with the } \\
\text { different } \\
\text { news } \\
\text { datasets. }\end{array}$ & $\begin{array}{l}\text { other } \\
\text { domai } \\
\text { ns. }\end{array}$ & \\
\\
\end{tabular}

